\title{
象牙質及ひ骨の水溶性物質についで
}

\author{
関 野格 郎 名倉啓一増井康男 \\ 東京医科歯科大学歯学部生化学教室（指導 荒谷教授） \\ 大森郁朗鬼久保博昭 岡田泰紀 \\ 東京医科歯科大学歯学部保存学教室 (主任 檜垣教授) \\ " " 生化学教室（指導 荒谷教授）
}

\section{Water-soluble Substances of Dentin and Bone}

\author{
Kakuro Sekino, Keiichi Nagura and Yasuo Masui \\ Department of Biochemistry (Prof. S. Araya) \\ Ikuo Ohmori, Hiroaki Onikubo and Yasunori Okada \\ Department of Operative Dentistry (Prof. R. Higaki) and \\ Department of Biochemistry (Prof. S. Araya) \\ School of Dentistry, Tokyo Medical and Dental University
}

1) Water-soluble substances of the triturated equine and bovine dentins and bovine bone, when suspended in distilled water and N/100 Veronal buffer, are studied by the determinations of calcium, magnesium, phosphorus and nitrogen.

2) The dissolution of magnesium ions of dentin considerably differs from that of bone, i.e. the ratio of magnesium and calcium dissolved from dentin $(\mathrm{Mg} / \mathrm{Ca})$ is much greater than that of bone, and in the case of bone it keeps nearly constant throughout the experiment period, but in the case of dentin the ratio shows an increasing inclination.

From these phenomenons it is suggested that dentin and bone hold magnesium ions in different manners respectively.

3) The ratio of water-soluble magnesium and calcium is much greater than that of the composition of magnesium and calcium in the both tissues.

4) The ratio of calcium and phosphorus dissolved from dentin $(\mathrm{Ca} / \mathrm{P})$ is fairly small (below 1.0). It seems that other phosphate salts are more soluble than calcium phosphate, since the ratio of calcium and phosphorus in $\mathrm{Ca}_{3}\left(\mathrm{PO}_{4}\right)_{2}$ gives 1.94 and in hydroxylapatite gives 2.15. But $(\mathrm{Mg}+\mathrm{Ca}) / \mathrm{P}$ gives nearly 2.0 when magnesium ions are also multiplied by the ratio of both molecular weights (40/24.3).

So it can be considered that the soluble magnesium ions are driven from some phosphate compounds such as tricalcium phosphate or hydroxylapatite in which calcium ions are replaced by magnesium ions.

On the contrary, the ratio of calcium and phosphorus dissolved from bone is greater than 2.3, especially in N/190 Veronal buffer, and it seems that other calcium salts are dissolved more than calcium phosphate is. 
5) According to the nitrogen determination, little difference is observed with the amount of dissolved organic compounds between dentin and bone.

本学歯学部の生化学教室では硬組織の構造を研 究する一つの手段として, 硬組織に種々な溶媒, キレート剤，酵素等を作用させてそれ等に対する 硬組織の化学的な反応性をしらべている。それ等 の試みの一つとして，まず硬組織を蒸溜水及び

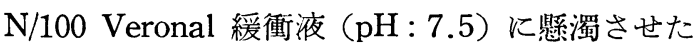
時に溶出して来る物質をしらべてみた。J.J.Martin 等 ${ }^{11}$ は歯牙粉末に有機の塩類を $37^{\circ} \mathrm{C}$ で 7 日 間作用させた時に溶出して来る $\mathrm{Ca}^{\#}$ 量をしらべ, 盲験として蒸溜水中に溶将出す $\mathrm{Ca}^{\#}$ 量もみてい るが, その場合にも $\mathrm{Ca}^{\#}$ の溶出は認められている。

我々は此等の溶媒の作用によつて溶出して来る 物質のうち, $\mathrm{Ca}^{+}, \mathrm{Mg}^{\#}, \mathrm{P}$ 及び $\mathrm{N}$ を時間を追つ て测定した。晌， $\mathrm{N}$ 量は溶出して来た有機物を分 解して测定したもので㐫るから，可溶性の有機物 の一つの消長を示すものであろと思われる。

\section{実験}

\section{I. 実験材料}

a) 試料

試料には象牙質と睯を角いたが，象牙質は馬及 び牛，骨は年を使つた。

馬及び半の象牙質は，それ等の菌牙粉末から浮 游法によつて分離して得たものであり ${ }^{21}$ ， 粉末の 大いさは標淮節によつて 100～200mesh に限定し た。牛骨は管状学の管翰部を角い骨膜及び骨髄を 除去して Acetone で洗滌，粉砕して 100 200 mesh の大いさの粉末とした。

b) 溶媒

i）蒸溜水

通常のガス式蒸溜装置によつて得たものを用い た。( $\mathrm{pH}: 5.8)$

ii) N/100 Veronal 緩衝液

Sodium Diethylbarbiturate $2.06 \mathrm{~g}$ を蒸溜水に 溶解，全容を 11 としたものと $\mathrm{N} / 100 \mathrm{HCl}$ とを

* 本研究は昭和 31 年度文部省科学研究費の援助によ り行われたものである。
$7: 3$ の割合に混じたもので, $\mathrm{pH} 7.5$ に調整して 颃く。

\section{II. 実験操作}

実験試料を溶媒量に対して $1 \%$ 割合に利りと り,これを magnetic stirrer 上の恒温槽に入れ て市る $200 \mathrm{ml}$ の三角コルベンにとつた溶媒に加 え， stirring を開始する。温度を $38^{\circ} \mathrm{C}$ に保ちな がら一定時間ごとに suspension の状態に㟧る， この溶液の一部を $10 \mathrm{ml}$ の駒込ピペットでとり出 し, 直ちに glass filter $3 \mathrm{G} 4$ で吸引滤過して試料 と溶媒とを分離し，その滤液を被検液とする。

\section{III. 各成分の測定方法}

1) $\mathrm{Ca}^{\#}, \mathrm{Mg}^{\#}$ の定量

M/100EDTA 溶液を滴定液とし，指示楽に Murexide (MX) と Phthalein Complexone(PC) を用いて，キレート滴定法 ${ }^{3)}$ によつて $\mathrm{Ca}^{\#}, \mathrm{Mg}^{H}$ の分離定量を行つた。即ち，被検液 $5 \mathrm{ml}$ を 100 $\mathrm{ml}$ の三角コルベンにとり, 共存重金属イオンの 隠敕羭として $\mathrm{N} / 25 \mathrm{NaCN}$ 溶液 $0.5 \mathrm{ml}$ (被検液の $\mathrm{pH}$ の上景を防ぐため，この浴液の添加量を少く した）及び $\mathrm{NH}_{4} \mathrm{OH}-\mathrm{NH}_{4} \mathrm{Cl}$ 緩衝液約 $1 \mathrm{ml}$ を加 えて $\mathrm{pH}=10$ となし，これに指示楽P Cを 1 滴榈 下（これを多量に入れすぎると Naphthol Green Bで適当に調整しておいたものでも，終点におい てPCの微紅色が残るから注意を要する）した後 M/100 EDTA 溶液で滴定した。紫色から䇥色に 変る点が終点である。この際, 滴定にかつつて来 るのは $\mathrm{Ca}^{\#}$ 及び $\mathrm{Mg}^{\#}$ である。

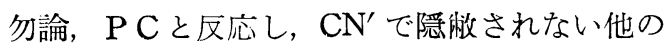
金属イオンも滴定にかつつて来るわけであるが, 歯牙及び骨ではそれ等の金属量は殆んど negligible である。次いで同一の被検液 $5 \mathrm{ml}$ をとり， $\mathrm{N} / 25 \mathrm{NaCN}$ 浴液を加元更に $\mathrm{IN} \cdot \mathrm{NaOH}$ 溶液約 1 $\mathrm{ml}$ を加えて $\mathrm{pH}=12$ となし， M/100EDTA 溶液 でMXを指示薬として滴定した。赤色から紫色に 変る点が終点である。この場合は, $\mathrm{Ca}^{\#}$ のみが测 定にかつつて来る。 
そこで，指示楽にP Cを用いて得た滴定值を $\mathrm{V}_{\mathrm{PC}}$ とし，指示薬に MX を用いて得た滴定值を V $\mathrm{MX}$ とすれば, 次の訫算によつて $\mathrm{Ca}^{+}, \mathrm{Mg}^{+}$を 算出することが出来る。

$$
\begin{aligned}
& \left(\mathrm{V}_{\mathrm{PC}}-\mathrm{V}_{\mathrm{MX}}\right) \cdot \mathrm{F} \times 0.243=\mathrm{Mg}^{\#}(\mathrm{mg}) \\
& \left(\mathrm{V}_{\mathrm{MX}}-\mathrm{BL}\right) \cdot \mathrm{F} \times 0.4=\mathrm{Ca}^{+}(\mathrm{mg})
\end{aligned}
$$

$\mathrm{F}$ ：滴定液の力価

$\mathrm{BL}$ ：被検液の代りに蒸溜水をとり，指示薬 にMXを用いて滴定した盲験值（この場 合，PC, MX の指示薬による滴定值の禁は 殆んどない)。

南, MXによる滴定の際に赤の余色である緑色 の眼鏡をフィルターとして用いると, 変色点がわ かり易い。

二種の金属指示楽による $\mathrm{Ca}^{\#}, \mathrm{Mg}^{\#}$ の分離定 量については，既に報告されているところである が，念のため次のような model test を行つた。 即ち, $200 r / \mathrm{ml} \mathrm{Ca}^{\#}$ 溶液及び $20 r / \mathrm{ml} \mathrm{Mg}^{\#}$ 溶液 （いずれも第一化学製，カルシウム標準液及びマグ ネシウム標準液を稀积調製したもの）を各 $10 \mathrm{ml}$ ずつ $100 \mathrm{ml}$ のメスコルベンにとり，蒸溜水を加 えて全容を $100 \mathrm{ml}$ としたものを試料とした。試 料を $10 \mathrm{ml}$ ずつとり, 指示楽に P C 及びMXを用 いて M/100EDTA 溶液で直接滴定した。测定值 は表 1 の通りである。理論值は $\mathrm{Ca}^{\mathrm{H}}=0.200 \mathrm{mg}$, $\mathrm{Mg}^{\mathrm{H}}=0.020 \mathrm{mg}$ であるから测定法の誤溉は約 $5 \%$ である。

\section{2) $\mathrm{P}$ の定量 (Ortho-P のみ)}

$\mathrm{P}$ の定量は Isobutanol 抽出法4)によつた。即

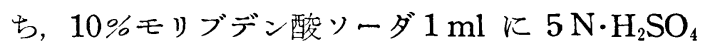
$1 \mathrm{ml}$ を加え，それに Isobutanol $4 \mathrm{ml}$ を加えた
ものを氷で充分泠却し，これに被検液 $1 \mathrm{ml}$ を速 かに加えて 15 秒間強く振盪した後, $22 \sim 23^{\circ} \mathrm{C}$ の 水浴中に入れ液相の分離を待つ(これに要する時 間は 40〜60秒である)。液相が分離したならば直 ちに駒込ピペットで Butanol 層を cuvette にう つしとり, spectrophotometer によつて波長 380 〜430m $\mu$ で比色した。

$\mathrm{P}$ 量は $\mathrm{P}$ 標集液 $(100 \% / \mathrm{ml})$ の吸光度との 比か ら求められる。即ち

$$
\begin{aligned}
& \frac{\mathrm{E}^{\prime}}{\mathrm{E}} \times 100=\mathrm{P} r / \mathrm{ml} \\
& \mathrm{E}^{\prime}: \text { 被検液の吸光度 } \\
& \mathrm{E}: 100 r / \mathrm{ml} \text { 標潐液の吸光度 }
\end{aligned}
$$

3) $\mathrm{N}$ の定量

被検液 $5 \mathrm{ml}$ を酸化管にとり，酸化して microKjeldahl 法のParnas の変法によつて测定した。

\section{実験成績並びに考按}

\section{I. 象牙質からの溶出狀況}

図 1，2，3 はそれぞれ馬及び牛の象牙質粉末を $1 \%$ 割合に蒸溜水及び N/100 Veronal 緩衝液 に賏濁させて，溶媒に溶出して来る $\mathrm{Ca}^{+}, \mathrm{Mg}^{+}$ 及び $\mathrm{P}, \mathrm{N}$ を 5 分, 15 分, 30 分, 1 時間, 3 時間 と時間を追つて测定した結果であるが，図の如く 微量ながら無機物及び有機物の溶出がみられ，て の溶出量は時間と共に増加している。侉, 蒸溜水 の $\mathrm{pH}$ は 5 分: $6.85,1$ 時間: $7.20,3$ 時間:

7.40 と僅かであるが上景した。

\begin{tabular}{|c|c|c|c|c|c|c|c|}
\hline \multicolumn{4}{|l|}{$\mathrm{PC}$} & \multicolumn{4}{|l|}{$\mathrm{MX}$} \\
\hline & $\mathrm{V}_{\mathrm{PC}}(\mathrm{m} \mathbf{l})$ & $\mathrm{V}_{\mathrm{PC}}-\mathrm{V}_{\mathrm{MX}}$ & $\mathrm{Mg}^{+} \quad(\mathrm{mg})$ & & $\mathrm{V}_{\mathrm{MX}}(\mathrm{ml})$ & $\mathrm{V}_{M X}-\mathrm{BL}$ & $\mathrm{Ca}^{\mathrm{H}}$ (mg) \\
\hline 1 & 0.581 & - & - & 1 & 0.502 & - & - \\
\hline 2 & 0.585 & - & - & 2 & 0.503 & - & - \\
\hline 平均值 & 0.583 & $0.080_{5}$ & 0.019 & 平均值 & $0.502_{5}$ & $0.492_{5}$ & 0.197 \\
\hline
\end{tabular}

1) $\mathrm{Ca}^{\#}$ と $\mathrm{Mg}^{+}$の溶出について

まず馬の象牙質粉末に蒸溜水を作用させた場合 （図1-A）であるが，作用時間 30 分を過ぎると

表 1

$\mathrm{BL}: 0.010$

BL : 0.010 


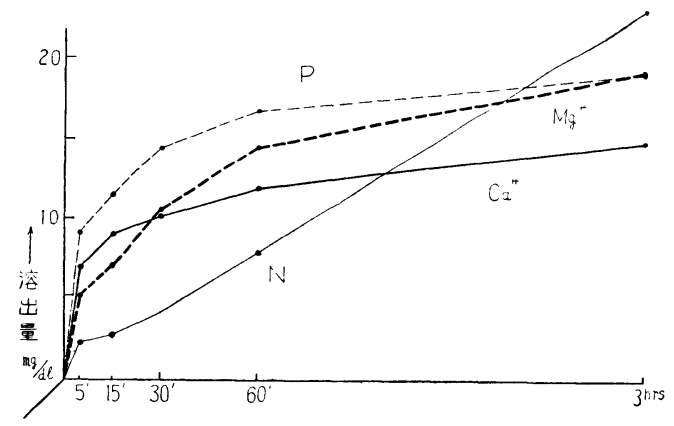

図 1-A 馬象牙質を水で抽出した場合

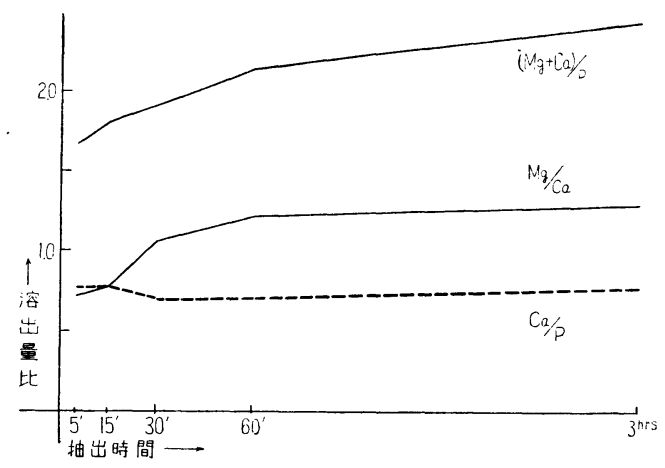

図1-B

$\mathrm{Ca}^{\#}$ の溶出量よりも $\mathrm{Mg}^{\#}$ の溶出量の方が多く, $\mathrm{Ca}^{\#}$ と $\mathrm{Mg}^{\#}$ の溶出量比 $\mathrm{Mg} / \mathrm{Ca}$ をとつてみると 図 1-B のようにその值は時間と共に稍々大きく なる傾向が認められ, $\mathrm{Mg}^{*}$ の溶出量が $\mathrm{Ca}^{\#}$ の溶 出量にくらべて時間と共に増加していることを示 している。

これを牛の象牙質についてみると(図 2 ), $\mathrm{Mg} / \mathrm{Ca}$ は馬よりもいくらか小さいが，それでも略々同じ 様な傾向が見られる。この傾向は馬の象牙質に溶 媒の $\mathrm{pH}$ を一定に保つために N/100 Veronal 緩 衝液を作用させた場合（図 3 ) にも認められる。 $\mathrm{Mg}^{\#}$ の溶出の比較的少い牛についてみてもこの $\mathrm{Mg} / \mathrm{Ca}$ は别に测定した同一試料の年象牙質 $\mathrm{Mg}^{\mathrm{H}}$

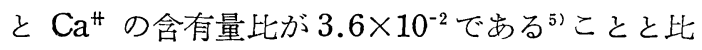
較すると枌違いに大きな值であることに気附く。 即ち, このような溶媒によつて象牙質粉末を抽出 すると, $\mathrm{Ca}^{+}$に比して $\mathrm{Mg}^{+}$が異常に速く抽出さ れてくることが示されている。

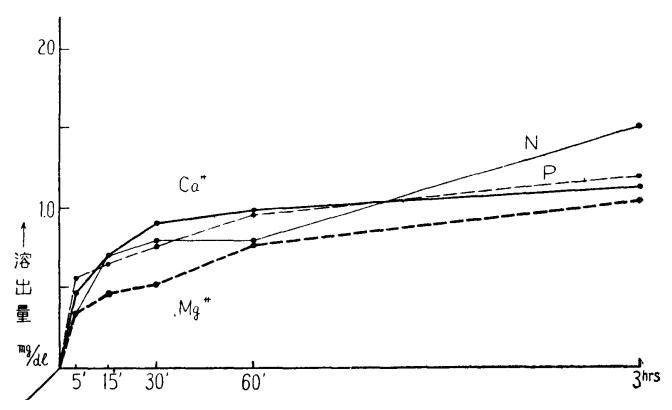

図 2-A 牛象牙質を水で抽出した場合

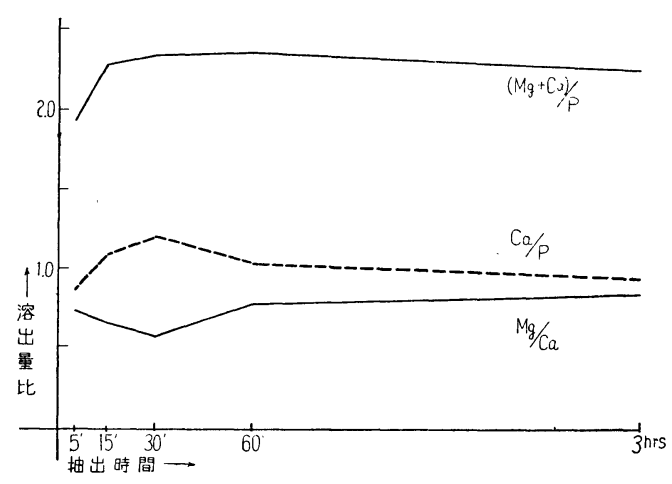

図 2-B

2） P及び有機物の溶出について

図 1，2，3に拈いてPの溶出量と $\mathrm{Ca}^{\#}$ の溶出 量の比 $\mathrm{Ca} / \mathrm{P}$ をしらべてみると大体 1.0 以下であ つて, $\mathrm{Ca}_{3}\left(\mathrm{PO}_{4}\right)_{2}$ の場合の 1.94, Hydroxylapatite の場合の 2.15 のうな 理論值からみると可 成り低い值を示している。従つてこの場合 $\mathrm{Ca}^{\#} に$ 比して大量に溶け出している燐酸は, 燐酸カルシ ウム以外の塩として出ている筈であるが, $\mathrm{Mg}^{+}$の 溶出量が比較的多いことから試みに溶出 $\mathrm{Mg}^{+}$量 を $\mathrm{Ca}^{\#}$ 量に換算して, その值を溶出 $\mathrm{Ca}^{\#}$ 量に加え たものと $\mathrm{P}$ との比 $(\mathrm{Mg}+\mathrm{Ca}) / \mathrm{P}$ をつてタると, 図 1 の場合は $1.99 \pm 0.28$, 図 2 の場合は $2.27 \pm$ 0.16 , 図 3 では $1.85 \pm 0.06$ と云う值を示し, ほ ऽ゙ $\mathrm{Ca}_{3}\left(\mathrm{PO}_{4}\right)_{2}$ 或いは Hydroxylapatite の $\mathrm{Ca} / \mathrm{P}$ の值に近い值を示すようになる。

このことから溶出する $\mathrm{Mg}^{+}$のかなりの部分は 燐酸カルシウム中の $\mathrm{Ca}^{\#} に \mathrm{Mg}^{\#}$ が置換したよ らな燐酸化合物に由来しているのではないかと想 


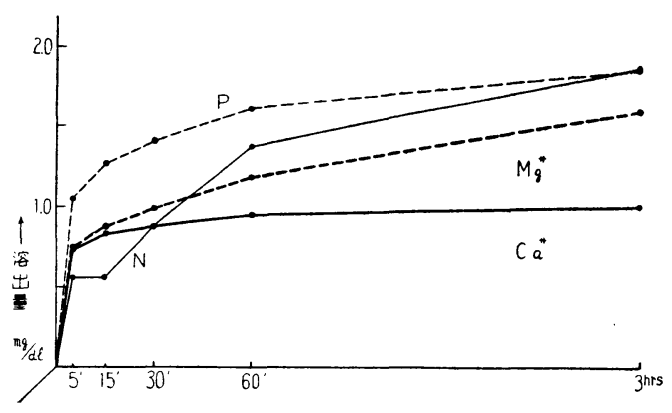

図 3-A 馬象牙質を N/100 Veronal 緩㣫液で抽出した場合

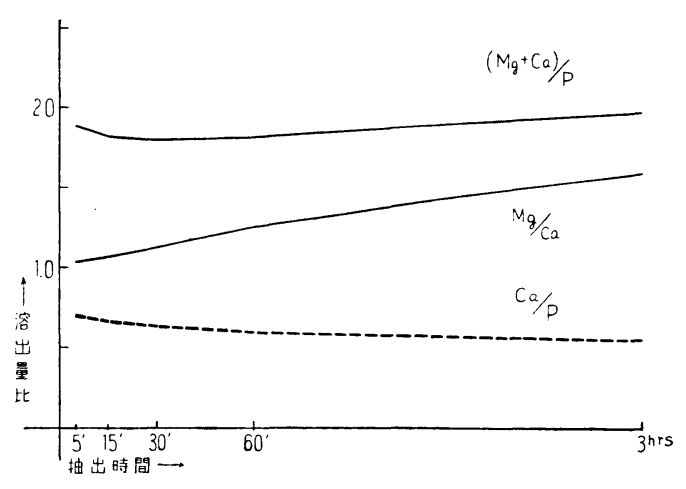

図 3-B

像される。

又, 有機物の溶出をその $\mathrm{N}$ 量からみると, これ も時間と共に増加している。

\section{II. 骨からの溶出狀況}

図 4 及び図 5 は象牙質の場合と同様，牛骨粉末 を蒸溜水及び $\mathrm{N} / 100$ Veronal 緩衝液に $1 \%$ 割 合に懸濁させた時に, 溶媒に溶出して来る $\mathrm{Ca}^{\#}$, $\mathrm{Mg}^{\#}$ 及び $\mathrm{P}, \mathrm{N}$ を時間を追つて测定した結果で 㐫る。

1) $\mathrm{Ca}^{\#}$ 及び $\mathrm{Mg}^{\#}$ の溶出について

蒸溜水を作用させた場合（図 4 ） \& N/100 Veronal 緩衝液を作用させた場合（図 5 ）も $\mathrm{Mg}^{+}$の 溶出量は少い。そしてこれは象牙質の場合と著し く異る点で家る。

$\mathrm{Ca}^{\#}$ と $\mathrm{Mg}^{\#}$ の溶出量比 $\mathrm{Mg} / \mathrm{Ca}$ をとつてみる と, 象牙質よりも小さく又, 象牙質の $\mathrm{Mg} / \mathrm{Ca}$ が 時間と共にや〉増加しているのに対して，いづれ の時間に执いても $0.3 \sim 0.4$ の值を示し, $\mathrm{Ca}^{\#}$ と

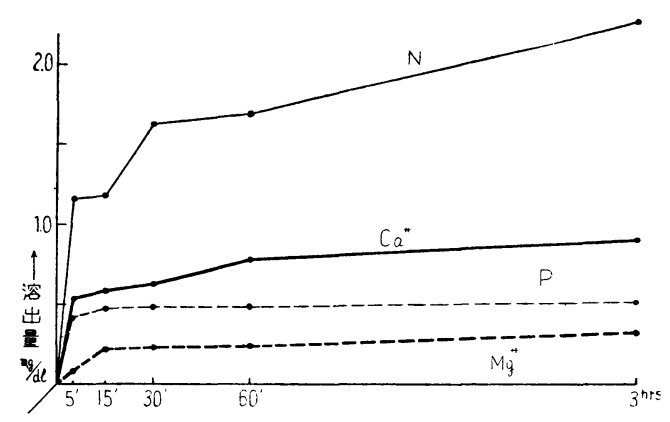

図 4-A 牛骨を水で抽出した場合

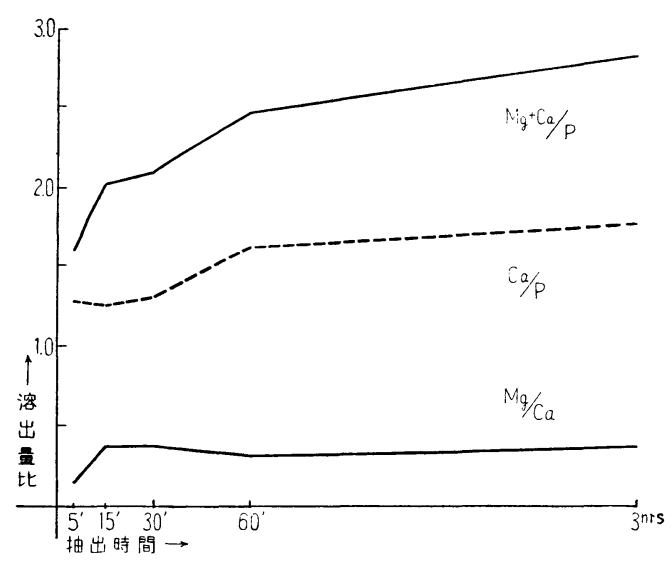

図 4-B

$\mathrm{Mg}^{\#}$ がほよ゙一定の割合で浴出していると考えら れる。しかし象牙質同様, $\mathrm{Mg}^{\#}$ の溶出は $\mathrm{Ca}^{\#} の$ 浴出に対して可成り多く, 別に同一試料の牛骨の $\mathrm{Ca}^{\#}, \mathrm{Mg}^{+}$の含有量比を测定した結果は1.9×10-2 であるらから，てれよりは著しく大きい值を示し ているわけで，骨でも $\mathrm{Mg}^{+}$は $\mathrm{Ca}^{\#}$ に比し比較 的溶け易い状態にあることが示されているようで 宛る。

2） P及び有機物の溶出について

$\mathrm{Ca} / \mathrm{P}$ をしらべてみると象牙質より大さな值を 示している。乞して, 蒸溜水を作用させた場合は 始め1.3位のものが次第に増大して 3 時間では 1.8 位になるが，N/100 Veronal 緩衝液を作用させた 場合では, 始め 2.0 位のものが 3 時間では 2.5 に

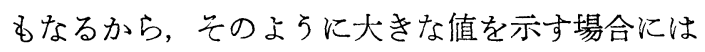
燐酸塩以外のカルシウム塩が浴出しているように 思われる。 


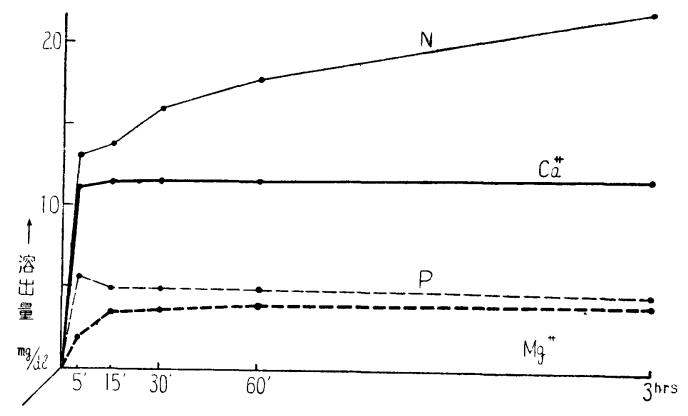

阀 5-A 牛骨を N/100 Veronal 緩衝液 で抽出した場合

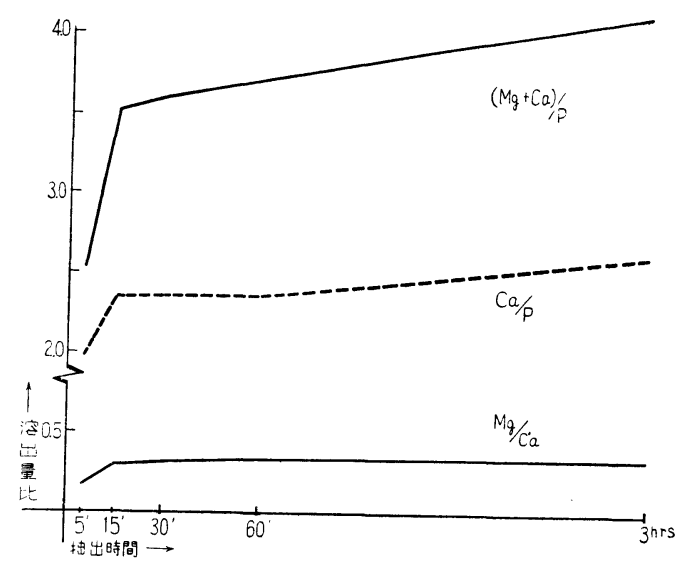

図 5-B

又, 象牙質の場合と同様に $(\mathrm{Mg}+\mathrm{Ca}) / \mathrm{P}$ をと つてみると, 水抽出の場合始めは 2 前後の值であ るが後にはやはり 2.5 以上にもなり, Voronal 抽出の場合は勿論 3.0 を越寸非常に大きな值に なつてしまう。従つてこの場合は溶け出て来た $\mathrm{Mg}^{\#}$ が燐酸の化合物であるといらことは想像し 難い。しかし, 勿論, 溶け出た $\mathrm{Mg}^{+}$は大部分燐 酸化合物であるが， $\mathrm{Ca}^{\#}$ の極めて多くが燐酸化合 物ではないと考えても倠支えはない。

倘, N测定からみた有機物の溶出については, 象牙質の場合と見るべき养違はないようである。

以上の如く象牙質と骨との溶出状況を比較して みて特徴的な前のみられるのは $\mathrm{Mg}^{*}$ の溶出状況 である。即ち, 象牙質からの $\mathrm{Mg}^{*}$ の溶出量は骨 のそれとくらべて著しく多く, $\mathrm{Ca}^{\#}$ の溶出量との 比 $\mathrm{Mg} / \mathrm{Ca}$ をみても象牙質の方が大きく 且つ又
その值は作用時間と共にいくらか大きくなる傾向 を示しているのに詨して，篔では作用時間と無関 係にほよ゙一定の值を示している。しかし，両組織 とも抽出液中の $\mathrm{Mg} / \mathrm{Ca}$ は本来乞の組織の含有す

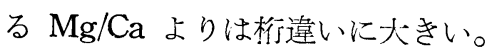

以上のような現象は両組織での $\mathrm{Mg}^{+}$の在り方 の相違を示唆しているものであり, 又, 両組織共 $\mathrm{Mg}^{+}$は Ca" に比して比較的このような条件で溶 け易い状態に㐫るものと考えられる。

\section{総括}

1）馬及び年の象牙質粉末と牛骨粉末を蒸溜 水, N/100 Veronal 緩衝液に懸濁させた時に溶出 する $\mathrm{Ca}^{\#}, \mathrm{Mg}^{+}, \mathrm{P}$ 及びN量を测定したところ， いずれの試料からも微量の溶出が認められた。

2) $\mathrm{Mg}^{+}$の溶出については，象牙質と骨とで は著しい相違がみられる。即ち, 象牙質の $\mathrm{Mg} / \mathrm{Ca}$

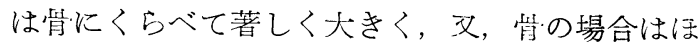
ぶ一定の值を示すのに対して, 象牙質の $\mathrm{Mg} / \mathrm{Ca}$ は時間と共に大きくなる傾向がある。

このことから, 両組織での $\mathrm{Mg}^{+}$の在り方の相 違が示唆される。

3）水溶性の $\mathrm{Mg} / \mathrm{Ca}$ の溶出量比は, 午象牙 質, 牛骨の $\mathrm{Mg} / \mathrm{Ca}$ の含有量比よりも著しく大き い。

4） $\mathrm{Ca} / \mathrm{P}$ をみると，象牙質は可成り小さく水 溶性の燐酸塩はカルシウム塩以外のものが多いと 考えられるが, $(\mathrm{Mg}+\mathrm{Ca}) / \mathrm{P}$ をつてみると，い ずれも 2.0 近辺の值を示す。このことから溶出す る $\mathrm{Mg}^{\#}$ は $\mathrm{Ca}_{3}\left(\mathrm{PO}_{4}\right)_{2}$ 或いは Hydroxylapatite 中の一部の $\mathrm{Ca}^{\#} に \mathrm{Mg}^{*}$ が置撸つたような燐酸化 合物に山来するものかもしれない。骨では殊に N/100 Veronal 緩衝液に䡞濁させた場合に 2.3以 上の值を示し, 燐酸塩以外のカルシウム塩が溶出 しているようである。

5） N测定から見た有機物の溶出は，象牙質と 骨で見るべき产違はないようである。

稿を終るに当り，御指導御校閲をたまわりました荒谷 真平教授並びに御校閲をたまわりました 檜垣麟三教授 
に深甚なる感謝の意を表します。

$$
\text { 交献 }
$$

1) Martin, J. J. et al. : Chelation, or metal-binding, as a new approach to the problem of dental caries, Revista Euclides 14 : 311, 1954.

2) 大森郁朗 : EDTA による畨牙の脱灰過程の研究一
殊にカルシウムと憐酸について, 口病誌。 $24: 135$, 1957.

3）上野景平: キレート滴定法, 東京, 1956, 南江堂, p. 132.

4) 中西茂子, 他: 無機燐酸の一定量法, 生化学 28 : 574, 1956.

5) 大森郁朗, 他 : EDTA に上る硬組織脱灰時の $\mathrm{Mg}^{\mathrm{H}}$ の溶出について. 口病誌. $24: 267,1957$. 